\title{
CRITICAL COMPILATIONS OF ATOMIC TRANSITION PROBABILITIES*
}

G. A. Martin, J. R. Fuhr, and W. L. Wiese

Center for Radiation Research

National Bureau of Standards

Gaithersburg, Maryl and 20899

\section{INTROOUCTION}

The NBS Data Center on Atomic Transition Probabilities is nearing completion of a critical compilation of atomic transition probability data on allowed and forbidden transitions in the elements scandium through nickel in all stages of ionization. This compilation constitutes a revision of a series of smaller NBS compilations published in recent years in the Journal of Physical and Chemical Reference Data. Upon completion of this project, work on updating of an even earlier compilation covering the elements hydrogen through neon will be initiated.

The world literature on atomic transition probabilities is collected and catalogued on an ongoing basis by the Data Center. A master reference list is maintained, and annotated bibliographies are issued as the number of new articles in the 1iterature and the resources of the Center permit. A computerized bibliographic database system is being developed to enhance the capability for handling bibliographical information in the NBS data centers on transition probabilities, line shapes and shifts, and energy levels. Development of a computerized database of critically evaluated numerical data on atomic spectroscopic quantities is planned for the future.

Exchange of information between the Center staff and both producers and users of transition-probability data is encouraged. User services include responding to requests for data and new references (those not yet included in a published bibliography), reception of visitors to the Center for use of the files, and consultation on technical matters. Receipt of research results from professionals in the field in advance of publication is welcomed.

\section{LIST OF PUBLICATIONS}

1. W. L. Wiese, M. W. Smith, and B. M. Glennon "Atomic Transition Probabilities (H through Ne--A Critical Data Compilation)," Nat. Stand. Ref. Data Ser., Nat. Bur. Stand. (U.S.) 4, Vol. I (U.S. Government Printing Office, Washington, D.C., 1966).

2. W. L. Wiese, M. W. Smith, and B. M. Miles "Atomic Transition Probabilities (Na through Ca--A Critical Data Compilation)," Nat. Stand. Ref. Data Ser., Nat. Bur. Stand. (U.S.) 22, Vol. II (U.S. Government Printing Office, Washington, D.C., $(1969) . \star \star$

3. B. M. Miles and W. L. Wiese "Critically Evaluated Transition Probabilities for Ba I and II," Nat. Bur. Stand. (U.S.) Tech. Note 474 (U.S. Government Printing Office, Washington, D.C., 1969); At. Data 1; 1-17 (1969). 
4. M. W. Smith and W. L. Wiese

"Graphical Presentations of Systematic Trends of Atomic Oscillator Strengths Along Isoelectronic Sequences and New Oscillator Strengths Derived by Interpolation," Astrophys. J. Supp1. Ser. 23, \#196, 103192 (1971).

5. J. R. Fuhr, W. L. Wiese, and L. J. Roszman ..

"Bibliography on Atomic Line Shapes and Shifts (1889 through March 1972)," Nat. Bur. Stand. (U.S.) Spec. Pub1. 366 (U.S. Government Printing Office, Washington, D.C., 1972).

6. M. W. Smith, G. A. Martin, and W. L. Wiese

"Systematic Trends and Atomic Oscillator Strengths," Nucl. Instrum. Methods 110, 219-226 (1973).

7. M. W. Smith and W. L. Wiese

"Atomic Transition Probabilities for Forbidden Lines of the Iron Group Elements (A Critical Data Compilation for Selected Lines)," J. Phys. Chem. Ref. Data 2, 85-120 (1973).

8. J. R. Fuhr, L. J. Roszman, and W. L. Wiese

"Bibliography on Atomic Line Shapes and Shifts (April 1972 through June 1973)," Nat. Bur. Stand. (U.S.) Spec. Publ. 366, Suppl. 1 (U.S. Government Printing Office, Washington, D.C., 1974).

9. W. L. Wiese and J. R. Fuhr

"Atonic Transition Probabilities for Scandium and Titanium (A Critical Data Compilation of Allowed Lines),".J. Phys. Chem. Ref. . Data 4 , 263-352 (1975).

10. J. R. Fuhr, G. A. Martin, and B. J. Specht

"Bibliography on Atomic Line Shapes and Shifts (July 1973 through May 1975)," Nat. Bur. Stand. (U.S.) Spec. Publ. 366, Supp1. 2 (U.S. Government Printing Office, Washington, D.C., 1975).

11. N. Konjevic and W. L. Wiese

"Experimental Stark Widths and Shifts for Non-Hydrogenic Spectral Lines of Ionized Atoms (A Critical Review and Tabulation of Selected Data)," J. Phys. Chem. Ref. Data 5, 259-308 (1976).

12. N. Konjevic and J. R. Roberts

"A Critical Review of the Stark Widths and Shifts of Spectral Lines from Non-Hydrogenic Atoms," J. Phys. Chem. Ref. Data $\underline{5}, 209-257$ (1976).

13. G. A. Martin and W. L. Wiese

"Tables of Critically Evaluated Oscillator Strengths for the Lithium Isoelectronic Sequence," J. Phys. Chem. Ref. Data 5, 537-570 (1976).

14. W. L. Wiese and S. M. Younger

"Atomic Oscillator Strengths in Fusion Plasma Research," Beam-Foil Spectroscopy, Vol. 2, pp. 951-960 (Plenum Publishing Corp., New York, N.Y., 1976). 
15. G. A. Martin and H. L. Wiese

"Atomic Oscillator Strength Distributions in Spectral Series of the

Lithium Isoelectronic Sequence," Phys. Rev. A 13, 699-714 (1976).

16. J. R. Fuhr, B. J. Miller, and G. A. Martin

"Bibliography on Atomic Transition Probabilities (1914 through

October 1977),". Nat. Bur. Stand. (U.S.) Spec. Publ. 505 (U.S.

Government Printing Office, Washington, D.C., Apr. 1978).

17. S. M. Younger, J. R. Fuhr, G. A. Martin, and W. L. Wiese

"Atomic Transition Probbilities for Vanadium, Chromium, and Manganese

(A Critical Data Compilation of Allowed Lines)," J. Phys. Chem. Ref. Data I, 495-630 (1978).

18. J. R. Fuhr, B. J. Miller, and G. A. Martin

"Bibliography on Atomic Line Shapes and Shifts (June 1975 through June 1978)," Nat. Bur. Stand. (U.S.) Spec. Pub1. 366, Supp1. 3 (U.S. Government Printing Office, Washington, D.C., 1978).

19. B. J. Miller, J. R. Fuhr, and G. A. Martin

"Bibliography on Atomic Transition Probabilities (November 1977

through March 1980," Nat. Bur. Stand. (U.S.), Spec. Pub1. 505, Suppl.

1 (U.S. Government Printing Office, Washington, D.C., Aug. 1980).

20. W. L. Wiese and G. A. Martin

"Wavelengths and Transition Probabilities for Atoms and Atomic Ions,"

Nat. Stand. Ref. Data Ser., Nat. Bur. Stand. (U.S.) 68, Part II.

"Transition Probabilities" (U.S. Goverrment Printing Office, Washington, D.C., 1980).

21. J. R. Fuhr, G. A. Martin, W. L. Wiese, and S. M. Younger

"Atomic Transition Probabilities for Iron, Cobalt, and Nickel (A Critical Data Compilation of Allowed Lines)," J. Phys. Chem. Ref. Data 10, 305-565 (1981).

22. W. L. Wiese and G. A. Martin

"Atomic Transition Probabilities," CRC Handbook of Chemistry and Physics, 63rd Edition, E334-E369 (CRC Press, Inc., Boca Raton, FL, 1982).

WORK IN PROGRESS

1. G. A. Martin, J. R. Fuhr, and W. L. Wiese

"Atomic Transition Probabilities (Sc through Ni--A critical Data Compilation)," J. Phys. Chem. Ref. Data, Suppl. (in preparation).

2. N. Konjevic, M. S. Dimitrijevic, and W. L. Wiese,

"Experimental Stark Widths and Shifts for Spectral Lines of Positive Ions (A Critical Review and Tabulation of Selected Data for the Period 1976 to 1982)", J. Phys. Chem. Ref. Data 13 (1984). [in press ] 
3. N. Konjevic, M. S. Dimitrijevic, and W. L. Wiese, "Experimental Stark Widths and Snifts for Spectral Lines of Neutral Atoms (A Critical Review of Selected Data for the Period 1976 to 1982)", J. Phys. Chem. Ref. Data 13 (1984). [in press]

\section{SERVICES}

Data, references, and technical information are supplied by the Center staff. Researchers who are interested in utilizing the services of the Center are invited to contact Georgia A. Martin, Jeffrey R. Fuhr, or Wolfgang L. Wiese either by mail or telephone [(301) 921-2071; FTS: 9212071)].

* Supported in Part by the Astrophysics Division of the National Aeronautics and Space Administration.

** Volume II of the NBS critical data compilation of atomic transition probabilities [W. L. Wiese, M. W. Smith, and B. M. Miles, Atomic Transition Probabilities--Sodium through Calcium, Nat. Stand. Ref. Data Ser., Nat. Bur. Stand. (U.S.) 22 (0ct. 1969)] is out of print. However, it can be purchased in hardcover form (photostatic copy) or microfiche from the National Technical Information Service (NTIS), order \#AD 696884 . For information on current price and method of payment, contact NTIS directly: Telephone (703) 487-4650, National Technical Information Service, U.S. Departinent of Commerce, 5285 Port Royal Road, Springfield, VA 22161 